\title{
Remedial Measures To Mitigate Pharmaceutical Industry Effluents On Groundwater In Bommasandra Industrial Area using MATALB
}

\author{
Shwetha. $\mathrm{A}^{1}$ and Dr.M Rajyalakshmi ${ }^{2}$
}

\begin{abstract}
Various estimates and projections indicate an increasing trend in water demand for agriculture, industrial and domestic uses in the coming decades. The discovery of a variety of pharmaceuticals in surface, ground, and drinking waters around the country is raising concerns about the potentially adverse environmental consequences of these contaminants. The areas around Bommasandra are concentrated with pharmaceutical industries. Analysis of water was done for pharmaceutical parameters like phenol, phosphate, chromium, BOD, COD, $\mathrm{p}^{\mathrm{H}}$, Total Solids, Coliforms and Sulphides. The parameters tested for surface water are within the limits and surface water samples in Bommasandra industrial area and its environs have BOD, COD, and phosphate beyond the permissible limit as prescribed by Indian Standards. MATLAB is used for preparing the graphs. Suitable bioremediation method was suggested for the removal of effluent. The experimental study proved that bioremedial measure can be effectively applied for the removal of pharmaceutical effluents. The results showed that cyanobacteria was used in removal of BOD up to $85 \%$ within 10 days.
\end{abstract}

Keywords - Pharmaceutical Parameters, Ground Water, MATLAB, Bioremediation, Ground water, BOD

\section{INTRODUCTION}

Water is an essential ingredient of pharmaceutical preparations and is used primarily for manufacture of oral preparations, besides washing of ampoules and bottles etc. Handling the wastewater streams involves basic and advanced wastewater treatment systems. Over the last decade, more than 100 different drugs have been found as environmental contaminants in effluents of sewage treatment plants, surface water, sediments, sludge, soils, groundwater and even drinking water sources .The widespread detection of pharmaceuticals in environmental samples as a result of improved analytical capabilities and focused field surveys has led to concern over the potential risks associated with releases of pharmaceuticals into the environment. The high polarity and low volatility of most pharmaceuticals means that they are likely to be transported to and by the water compartment. In recent years it has been clear that pharmaceuticals

\footnotetext{
${ }^{1}$ Department of Civil Engineering Global Academy of Technology, Bangalore, Karnataka, India

${ }^{2}$ Department of Civil Engineering BMS College Of Bio-Technology, Bangalore, Karnataka, India
} 
released into the environment are an important group of environmental pollutants. Many reports have been published that proves the widespread occurrence of these pollutants in waste water, ground water and surface water.

Pharmaceuticals that are made to interact with living organisms can also have acute effects on fauna and flora, but due to low concentrations this will not be the biggest concern. Studies on antibiotics have shown that up to $95 \%$ of antibiotic compounds can be released unaltered into the sewage system. Moreover, higher concentrations of antibiotics can lead to change in microbial community structure and ultimately affect food chains. The long term exposure of lower concentration of complex pharmaceutical mixtures on stream biota may result in acute and chronic damages, behavioral changes accumulation in tissues, reproductive damage and inhibition of cell proliferation. Several studies have demonstrated that fish exposed to wastewater effluents can exhibit reproductive abnormalities.

Globally, the detection of waste pharmaceuticals in the environment creates the risks, which are associated with their introduction into human, aquatic life and wildlife and is becoming a serious problem equally for both regulators and the pharma industry. Significant success on this issue is simply not achievable with the currently limited state of knowledge on environmental transport, fate, and effects of pharmaceuticals. There is need to take into consideration the possible growing effects of different drugs. Risk assessment of the pharma chemicals involves the detection of the inherent hazards at each stage and an estimation of the risks due to these hazards.

\section{OBJECTIVE OF THE STUDY}

- Identification of the study area and location of minimum 35 number of bore wells and surface water sources surrounding the study area for collection of samples.

- Collection of samples from the bore wells and surface water sources at intervals of 20 days and conducting analysis for water quality parameters on the composite sample collected at the end of 3 months.

- Curve fitting for the obtained results using MATLAB and suggesting suitable Bioremedial measures.

\section{III.REVIEW OF LITERATURE}

[1] Bharat Ghimire (2012) Conducted a study on "Ground Water Quality (Physico-Chemical) Analysis of Kalimati Area" was carried out in the month of February and March of 2012. Five representative households were selected on random basis of Kalimati area and the ground water samples from them were collected (4 shallow dug wells and one deep bored tube well) and their physical and chemical parameters were analysed on the lab following standard techniquesfor water sample collection and analyses described in Standard Methods for theExamination of Water \& Wastewater (APHA, 1998). Some parameters like turbidity, nitrate, total hardness \& iron were found greater than the standard value in the few samples.

[2] Chanti BabuPatneedi et. al. (2015) Conducted a study on on "Impact Of Pharmaceutical Wastes On Human Life And Environment" explains pharmaceutical compounds are being merged into the 
environment in extremely largequantities regularly and present system of regulations of their release is not able to control the untreated or partially treated pharma effluents. The impacts of drugs are entering into and occurring on ecosystems, biota and humans. The side effects on human, aquatic and animal health need to be investigated through thorough safety and toxicological studies.

[3] Idris M. A et. al. (2013) Conducted a study on on "Pharmaceutical Industrial Effluent: Heavy Metal Contamination of Surface water in Minna, Niger State, Nigeria" have explained Pharmaceutical effluent and surface water from River GoraxMaitumbi industrial layout Minna, Niger State, Nigeriawere Sampled at eight different points designated as S1 to S8. Elemental analysis was conducted over a period of 3 months, using Perkin-Elmer Analyst 300 Atomic Absorption Spectroscopy (AAS). The result shows that of the level of the elements was found to vary between the sample points.

[4] U. Stottmeister et al (2003) Conducted a study on on "Effects of plants and microorganisms in constructed wetlands for wastewater treatment" explains constructed wetlands are a natural alternative to technical methods of wastewater treatment. However, our understanding of the complex processes caused by the plants, microorganisms, soil matrix and substances in the wastewater, and how they all interact with each other, is still rather incomplete. In this article, a closer look will be taken at the mechanisms of both plants in constructed wetlands and the microorganisms in the root zone which come into play when they remove contaminants from wastewater. The supply of oxygen plays a crucial role in the activity and type of metabolism performed by microorganisms in the root zone.

\section{MATERIALS AND METHODOLOGY}

Details Of The Study Area

Bommasandra village is lies between latitude $12.80^{\circ} \mathrm{N}$ and $77.69^{\circ} \mathrm{E}$ is bounded on northwest by Hosur and on the north and northeast by Tumkur district, on the east by district and south by Krishna giri and Channapatna. The city is situated at an elevation of $450 \mathrm{~m}$ above MSL.

There are more 10 pharmaceutical industries in Bommasandra which produce tonnes of pharmaceutical products every year.The process of drug manufacturing can be broken down into a series of unit operations, such as milling, granulation, coating, tablet pressing, and others.

\section{LOCATION OF 35 BOREWELL AND SURFACE WATER POINT}

Among the several pharmaceutical companies present in Bommasandra, one of them was chosen as the centre. From the centre north, south, east and west directions were marked and bore well points were located at a distance of $10 \mathrm{~km}$ radius from the centre. The latitude, longitude of the bore well points as well as the surface water source were noted. The address of the points marked were also taken. The local residents were also interviewed for their source of supply for water for drinking and domestic use. 


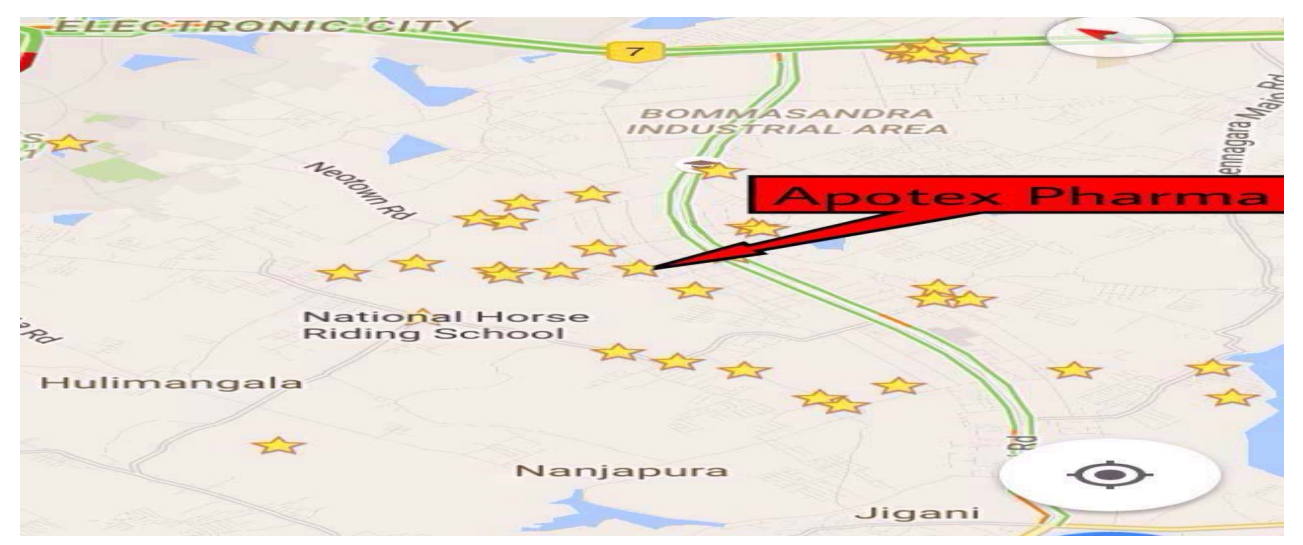

Figure 2 : Location of the bore well points from the centre chosen

\section{RESULT AND DISCUSSIONS}

\section{MATLAB AND CURVE FITTING}

Curve fitting is the use of mathematics, physics and computer science to study the behaviour of complex systems by computer simulation. It contains numerous variables that characterize the system being studied. Simulation is done by adjusting these variables and observing how the changes affect the outcomes predicted by the model. The results simulations help researchers make predictions about what will happen in the real system that is being studied in response to changing conditions. Here we use MATLAB for preparing the graphs. The curve fitting graph developed can be used to predict the ground and surface water quality parameters of the area surrounding the study area.

\section{Variation Of BOD Along With Time}

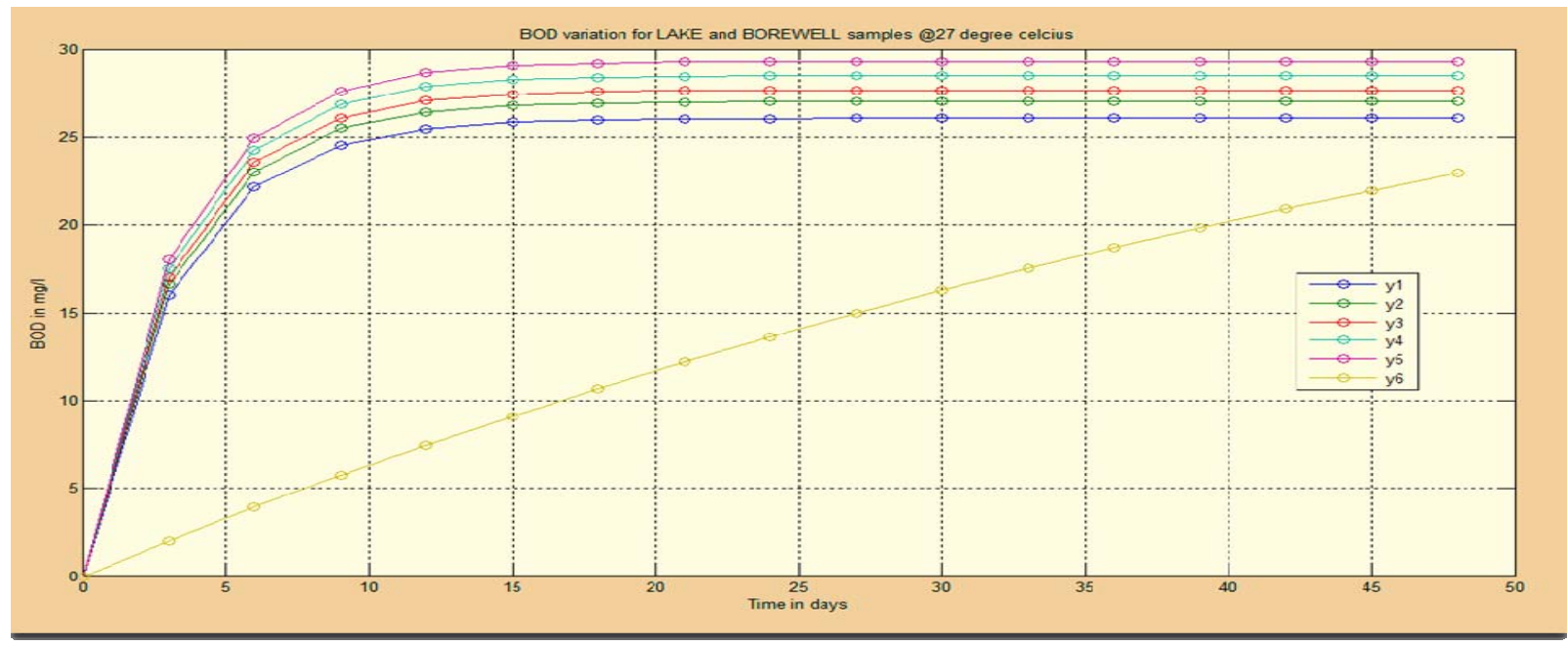

Fig 3: Variation of BOD along with time @ $27^{\circ} \mathrm{C}$ 


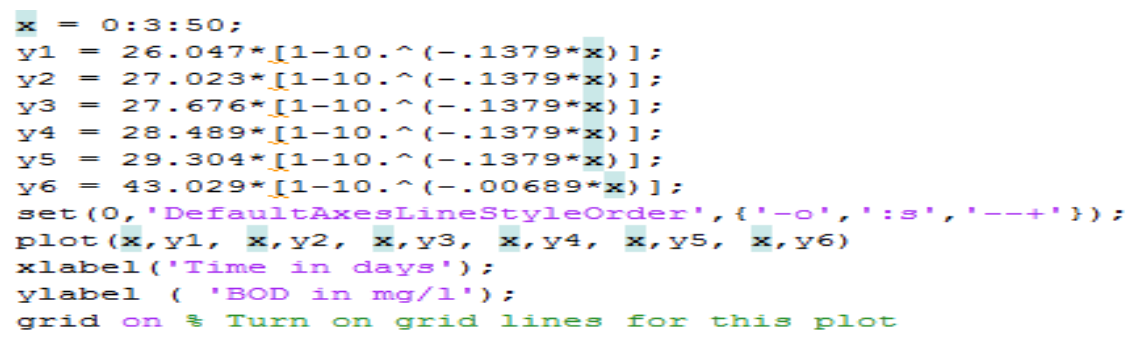

Table 1: Program for variation of BOD along with time @ $27^{\circ} \mathrm{C}$

From the Fig and table it can be understood that the BOD decomposes completely by the end of 15 days and hence becomes a constant. The temperature is kept constant i.e. $27^{\circ} \mathrm{C}$ and the duration is varied. The equation that is used is

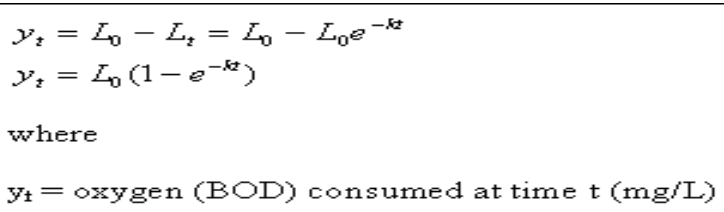

\section{Variation Of BOD With Temperature}

Variation OfBOD@45ㄷ

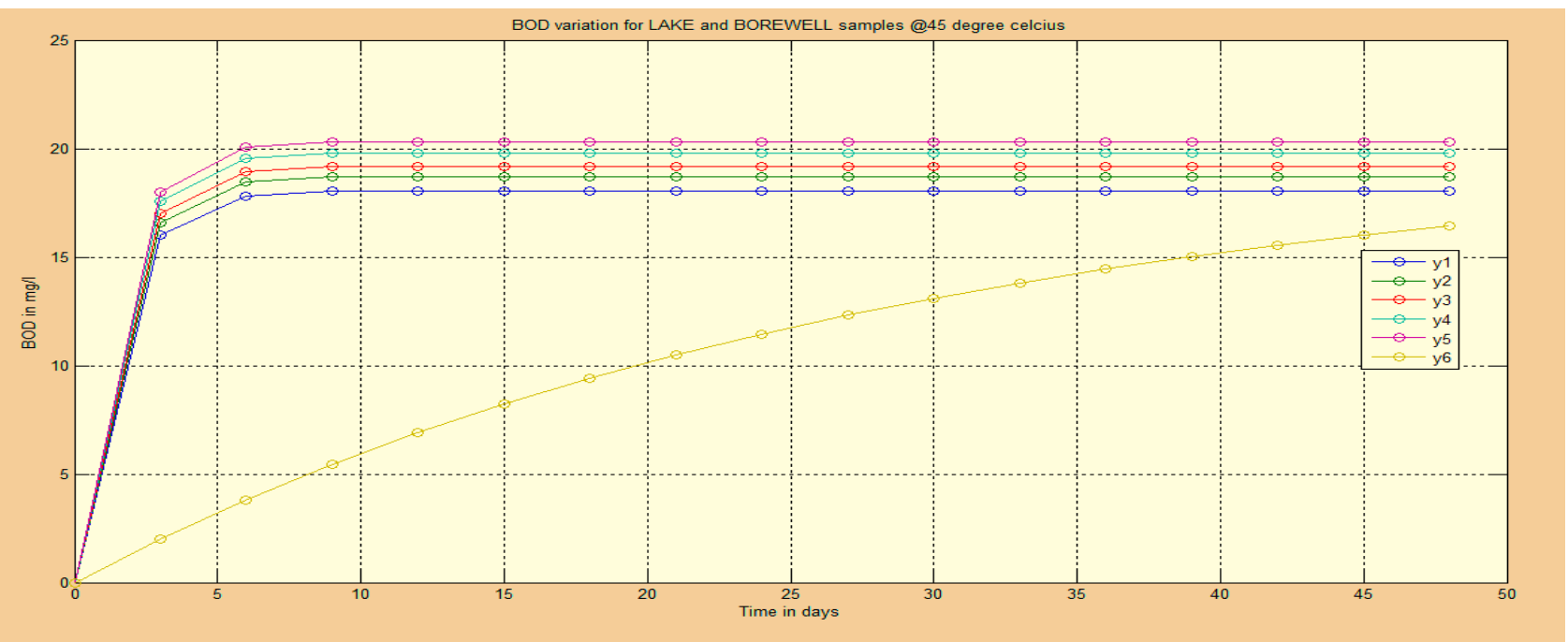

Fig 4: Variation of BOD along with time $@ 45^{\circ} \mathrm{C}$ 
Remedial Measures To Mitigate Pharmaceutical Industry Effluents On Groundwater In Bommasandra Industrial Area using MATALB

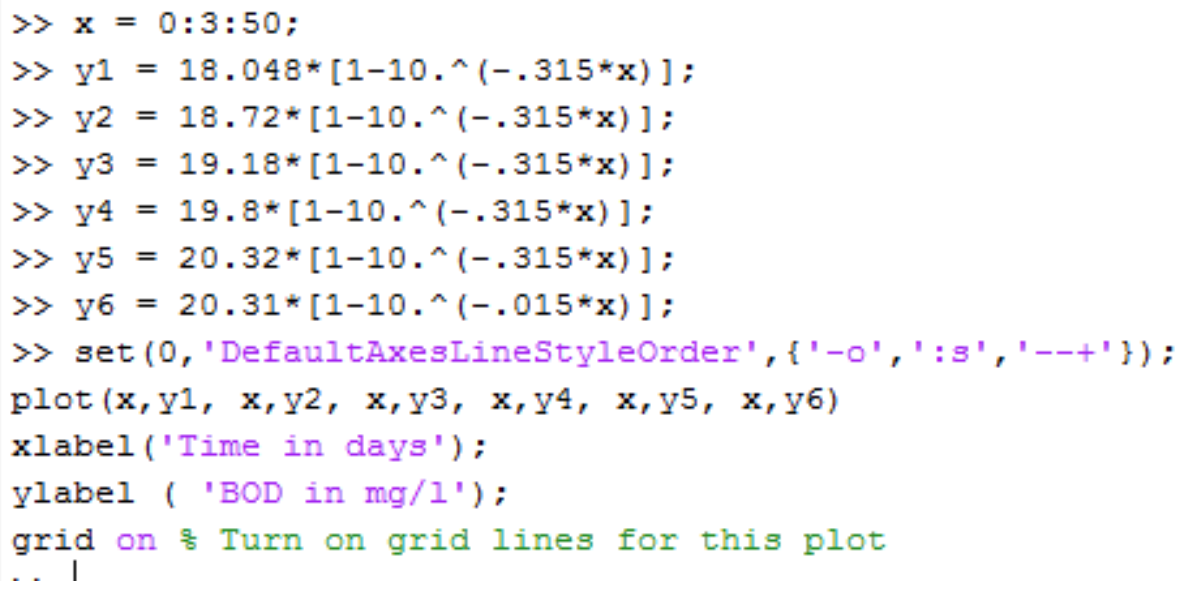

Table 2: Program for variation of BOD along with time @ $45^{\circ} \mathrm{C}$

\section{Variation Of BOD @65 ${ }^{\circ} \mathrm{C}$}

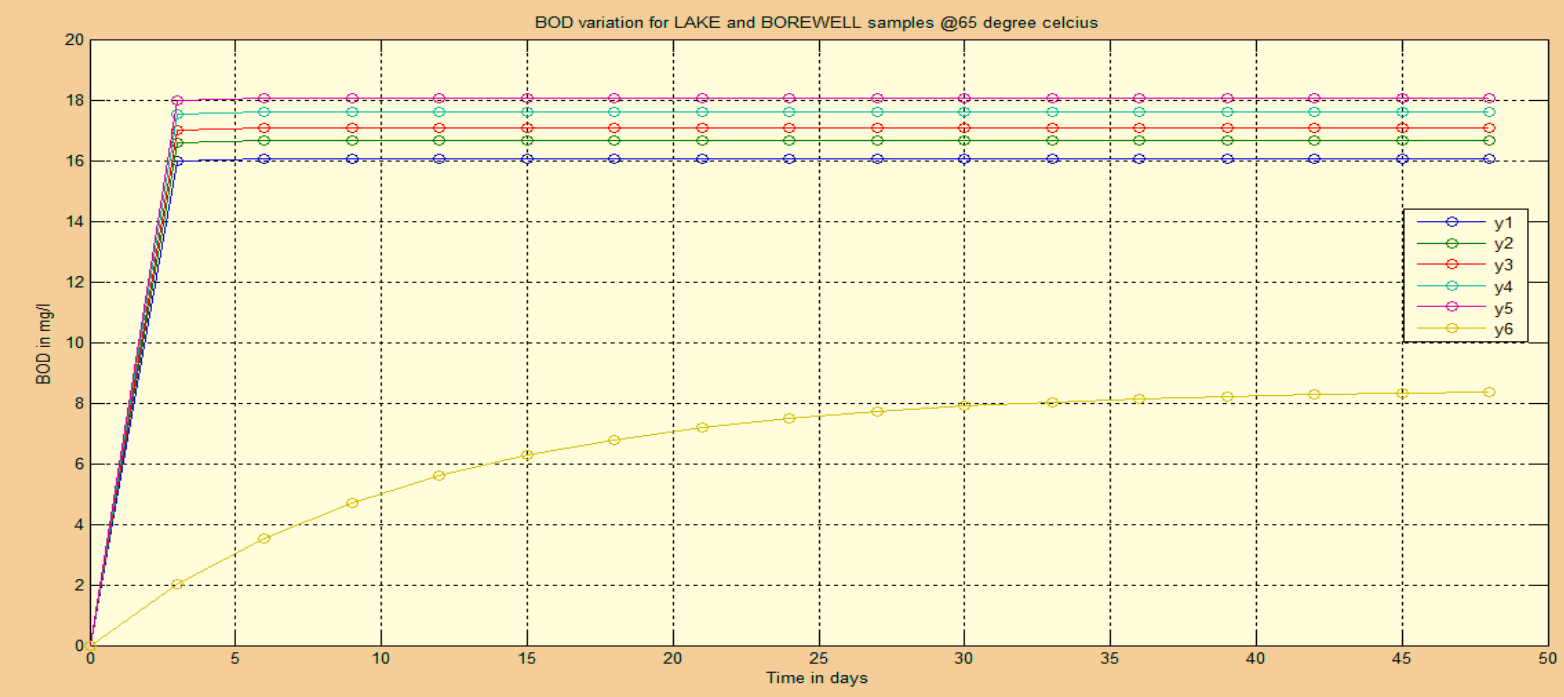

Fig 5: Variation of BOD along with time @ $65^{\circ} \mathrm{C}$ 


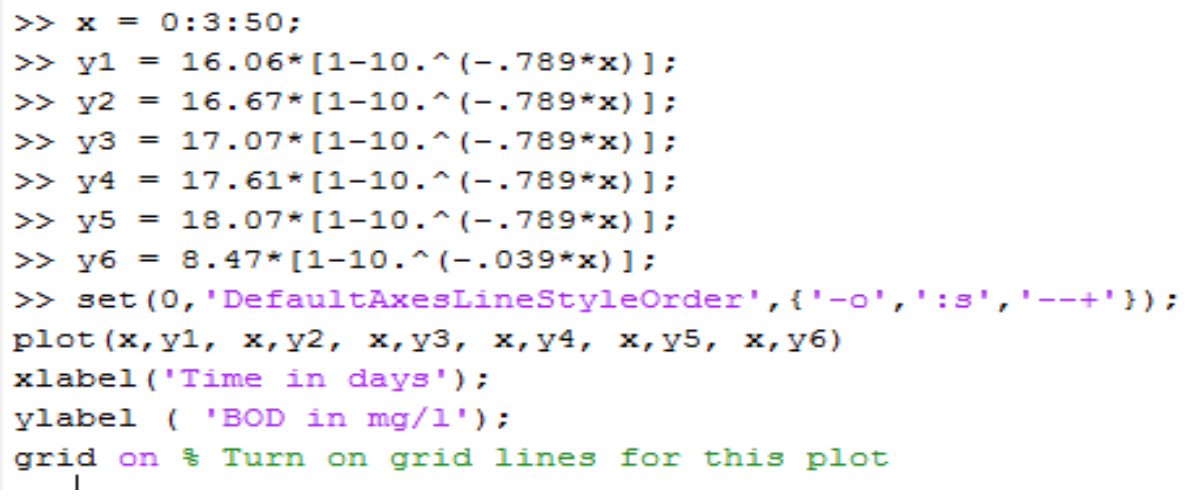

Table 3: Program for variation of BOD along with time $\left(a, 65^{\circ} \mathrm{C}\right.$

The biochemical reactions are temperature dependent and the activity of the microorganism increases with the increase in temperature up to certain value and drop with decrease in temperature. Since, the oxygen utilization in BOD test is caused by microbial metabolism, the rate of utilization is similarly affected by the temperature. The BOD content at $65^{\circ}$ is seen to be more than that at $45^{\circ}$.

\section{MICROBIAL TREATMENT}

The cyanobacteria growth completes at the end of 28 days. After the growth, it is mixed with one litre of the sample. The results showed that there was removal of BOD up to $85 \%$ within 10 days.

\section{CONCLUSIONS}

1. The results indicate that lake water quality for pharmaceutical parameters were beyond the permissible limits in the industrial area and its environs.

2. The ground water quality for pharmaceutical parameters were within the permissible limits

3. The borewell water is crystal clear, odourless and palatable and a few sample points are of the salty taste.

4. The lake water samples in Bommasandra industrial area and its environs have BOD, COD, and phosphate beyond the permissible limit as prescribed by Indian Standards

5. The experimental study proved that bioremedial measure can be effectively applied for the removal of pharmaceutical effluents.

6. Cyanobacteria are effective in removing BOD, COD and phosphate.

7. A computational model clearly gives the duration for the effluents to decompose.

\section{ACKNOWLEDGEMENTS}

I am thankful Professor and Head, Dept of Civil Engineering, and Head, Dept of Bio Technology, Principal of Global Academy Of Technology and BMS College of Engineering for their timely help rendered and the immense support extended for the submission of this paper. 


\section{REFERENCES}

[1] Olivier Cardoso, Jean-Marc Porcher, Wilfried Sanchez "Factory-discharged pharmaceuticals could be a relevant source of aquatic environment contamination'"'Elsevier, vol.115 20-30(2014).

[2] Idris, M. A*., Kolo, B. G., Garba, S. T. and Waziri, I. "Pharmaceutical Industrial Effluent: Heavy Metal Contamination of Surface water in Minna, Niger State, Nigeria" Academy for Environment and Life Sciences,vol.2[3]:40-44 Feb2013.

[3] Bharat Ghimire" on "Ground Water Quality (Physico-Chemical) Analysis of Kalimati Area" Central department of environmental Science, Oct 2012.

[4] Chanti Babu Patneedi* and K. Durga Prasadu "IMPACT OF PHARMACEUTICAL WASTES ON HUMAN LIFE AND ENVIRONMENT “ RJC, (Vol. 8) No.1 (67-70) January - March 2015.

[5] Stottmeister U1, Wiessner A, Kuschk P, Kappelmeyer U, Kästner M, Bederski O, Müller RA, Moormann H. "Effects of plants and microorganisms in constructed wetlands for wastewater treatment" Elsevier, Volume 22, Issues 1-2, December 2003, Pages 93-117.

[6] Kamaldeep, Madhuri S. Rishi, Naresh Kochhar And Nibedita Ghosh "Impact Of Industrialization On Groundwater Quality - A Case Study Of Baddi-Barotiwala Industrial Belt, Distt. Solan, Himachal Pradesh, India" Journal for Industrial Pollution Control, 27(2)(2011) pp 153-159.

[7] V.B. Sauer "Standards for the Analysis and Processing of Surface-Water Data and Information Using Electronic Methods” Water-Resources Investigations Report 01-4044.

[8] A. I. Omoike And G. W. Vanloon*" Removal Of Phosphorus And Organic Matterremoval By Alum During Wastewatertreatment" Elsevier, Vol. 33, No. 17, pp. 3617-3627, 1999

[9] H Huang, L.Tang “Treatment of organic waste using thermal plasma pyrolysis technology" Elsevier, Energy Conversion and Management 48 (2007) 1331-1337

[10] Jerker Fick, Hanna So “ Derstro “ M, Richard H. Lindberg, Chau Phan, Mats Tysklind, And D.G. Joakim Larsson "Contamination Of Surface, Ground, And Drinking Water From Pharmaceutical Production” Environmental Toxicology And Chemistry, Vol. 28, No. 12, Pp. 2522-2527, 2009.

Khwaja M. Anwar, Vanita Aggarwal “Analysis of Groundwater Quality of Aligarh City, (India): Using Water Quality Index” Current World Environment, Vol. 9(3), 851-857 (2014). 